\title{
ANALYTICAL STUDY OF THE XIV CENTURY WALL PAINTING AND LIME MORTARS IN THE "ST. GEORGE" CHURCH IN STARO NAGORIČANE, REPUBLIC OF MACEDONIA
}

\author{
Lidija Robeva-Čukovska $^{1^{*}}$, Tena Šjjakova-Ivanova ${ }^{2}$ Živko Kokolanski $^{3}$ \\ ${ }^{1}$ National Conservation Center - Central Chemical Laboratory for Cultural Heritage, \\ Josif Mihajlović No. 7, 1000 Skopje, Republic of Macedonia \\ ${ }^{2}$ Faculty of Natural and Technical Sciences, Goce Delčev University, 2001 Štip, Republic of Macedonia \\ ${ }^{3}$ Faculty of Electrical Engineering and Information Technologies, Ss Cyril and Methodius University, \\ 1000 Skopje, Republic of Macedonia \\ lidija2603@gmail.com
}

This work presents the first comprehensive study of the wall painting in the "St. George" church accomplished mainly by means of Fourier Transform Infrared Spectroscopy using Diffuse Reflectance and Micro-Infrared method (FTIR/DRS/Micro-IR) and the other analytical techniques Optical microscopy (OM), X-Ray Fluorescence (XRF), X-Ray Diffraction (XRD) and Inductively Coupled Plasma - Mass Spectrometry (ICP-MS). The main research objective was characterization of the artistic palette and painting technique, but also determination of the degradation products and observed alterations to the wall painting. Additionally, the lime mortars (plaster and renders) located immediately behind the studied wall painting were analyzed. The analysis demonstrated that mainly natural/mineral pigments were used in the artwork and the majority of painting was executed in combination of fresco and lime-painting technique. The major risk factor in the painting deterioration was found to be the salt efflorescence, which mostly occurred as oxalates and sulfates.

Keywords: wall painting; pigments; binders; degradation products; lime mortars

\section{ИСПИТУВАЊЕ НА УИДНОТО СЛИКАРСТВО И ВАРОВИТЕ МАЛТЕРИ ОД ХІV ВЕК ВО ЦРКВАТА „СВ. ЃОРЃИ“ ВО СТАРО НАГОРИЧАНЕ, РЕПУБЛИКА МАКЕДОНИЈА}

\begin{abstract}
Овој труд претставува прво опсежно испитување на sидното сликарство во црквата „Св. Ѓорѓи“ со помош на Фуриеова трансформна инфрацрвена спектроскопија (FTIR) користејќи дифузна рефлексиона (DRS) и микро-инфрацрвена спектроскопија (Micro-IR), како и со примена на оптичка микроскопија (OM), рендгенска флуоресценција (XRF), рендгенска дифракција (XRD) и масена спектрометрија со индуктивно спрегната плазма (ICP-MS). Главна цел на испитувањата беше карактеризација на уметничката палета и сликарската техника, но и одредување на настанатите промени и деградациони продукти на зидното сликарство. Во овој труд е претставена и анализата на варовите малтери коишто се употребени во сликарската подлога и во носечката конструкција на sидното сликарство. Аналитичките резултати посочија дека во sидното сликарство се употребени земјени/минерални пигменти применувајќк комбинација на фреско и варова техника на сликање. Главен причинител на деструкцијата на сликарството е солната ефлоресценција која главно е образувана од оксалатни и сулфатни соли.
\end{abstract}

Клучни зборови: зидно сликарство; пигменти; врзива; деградациони продукти; варови малтери 


\section{INTRODUCTION}

The "St. George" church (1313-1318 year) in the village of Staro Nagoricino close to Kumanovo in the Republic of Macedonia is one of the most valuable Byzantine monuments, representing an impressive architecture and artistic mastery attributed to the prominent medieval iconographers Mihajlo Astrapa and Evtihij [1]. The study reported in this paper was an integral part of the interdisciplinary project which was designed for conservation and revitalization of the entire Monastery complex [2].

The literature review revealed few reports associated with the "St. George" church, which were mainly devoted to the history, iconography and the architectural features of this monument [1]. The first research works on this monument followed by architectural interventions date back to the thirties of the last century $[1,3]$. The available documentation [3] reveals that three conservation projects were conducted in the period 1960-1997. Certain preservation interventions have been implemented, such as cleaning of the pictorial surface and consolidating the damaged area. However, there is a lack of relevant information about the consolidative materials used. Moreover, the wall paintings in this church have never been the subject of analytical study.

Hence, this paper represents the first comprehensive study of the wall painting in "St. George" church, primarily devoted to the identification of pigments and binders, allowing characterization of the original artistic palette and the used painting technique. Furthermore, the determination of the degradation products and alterations observed on the wall painting was in the scope of this research. This work also comprises the examination of the lime mortars established in the multi-layered walls that revealed the structure of the painting carrier.

Many publications demonstrate an extensive range of complementary analytical techniques and methods required in heritage artworks research [46]. The need of a multi method approach in the wall painting analysis is primarily due to variability in the constitutive materials (organic and inorganic) that can be encountered in the artwork.

The analysis reported in this paper was accomplished by means of Optical microscopy (OM), Fourier Transform Infrared Spectroscopy using Diffuse Reflectance and Micro-Infrared method (FTIR/ DRS/Micro-IR), X-Ray Fluorescence (XRF), XRay Powder Diffraction (XRD) and Inductively Coupled Plasma-Mass Spectrometry (ICP-MS). The FTIR analyses demonstrated prominent achievements in the determination of inorganic and organic substances in a single micro-sample. The determination of organic materials in the wall painting is a challenging task because its amount is much smaller than inorganic content associated with the pigments, salts, lime plaster and fillers. Consequently, the obtained IR spectra are most often complicated since overlapping and distorted bands occur. In this study, the resolution of the absorption spectra was improved by the use of derivative spectroscopy allowing a determination of the overlapped or hidden bands. The second derivatives of the original spectra were calculated using Savitzky-Golay method provided by the IRSolution 1.5 software (Shimadzu Corporation).

The identification of the pigments used was achieved with the complementary techniques XRF and $\mathrm{XRD}$, showing that mainly natural/mineral pigments were used in this painting. The chemical analysis of the mortars carried out by use of XRD and ICP-MS determined different mix proportions (binder/aggregate ratio).

The analytical findings encouraged the historical and artistic interpretation of the iconography and were found to be applicable in the immediate interventions on the painting in terms of cleaning the pictorial sequences, consolidation and preparation of restoration materials analogous to the original ones.

\section{EXPERIMENTAL SECTION}

\subsection{Instrumentation}

Optical microscopy. Micro-samples were embedded in polyester resin (Dugapol H-230 P) according the procedure [7] in order to prepare cross sections allowing stratigraphic examination and the study of subsequent layers. The hardened resin matrix was polished using a rotating disc covered by $\mathrm{SiC}$ grinding papers (Struers) with grits in the range 500-2400. Cross-sectioned microsamples were examined in reflected light and UV light with magnifications of $50 \times, 100 \times$ and $200 \times$ using Axioplan 2 microscope (Zeiss) equipped with a high resolution digital camera.

Infrared spectroscopy. The analyses were accomplished by using an IRPrestige 21 spectrophotometer (Shimadzu, Japan), capable of Diffuse Reflectance Spectroscopy (DRS) and Micro-infrared analysis (Micro-IR). The DRS analysis was performed by using a DRS-8000 attachment (Shimadzu). The powdered samples were first mixed with $\mathrm{KBr}$ producing $2 \%$ mixtures and then placed into a sample cup ( $2 \mathrm{~mm}$ diameter; $1 \mathrm{~mm}$ depth) which is a component of the DRS equipment. The 
spectra were recorded in the spectral range 400 $4000 \mathrm{~cm}^{-1}$ at a resolution of $2 \mathrm{~cm}^{-1}$ with 62 scans.

The micro-infrared spectra were acquired on $70 \times 70 \mu \mathrm{m}^{2}$ of the pictorial surface of the fragments with a size of about $1 \mathrm{~mm}$. The paint fragments were first placed in a micro-compression cell (Thermo Scientific) equipped with two IRtransparent diamond windows which allow sample sandwiching under moderate compression. Then, the diamond cell was placed on an IR microscope (AIM-8800, Shimadzu) and spectra were recorded in the $4000-600 \mathrm{~cm}^{-1}$ region with 162 scans and 2 $\mathrm{cm}^{-1}$ resolution in reflection mode using a Cassegrain reflecting objective $(15 \times)$.

X-ray fluorescence. The XRF Spectro Midex spectrometer equipped with Molybdenum X-ray tube and SDD detector system was used. The source was operated at $38 \mathrm{kV}, 5.9 \mathrm{~mA}$ and acquisition time of $120 \mathrm{~s}$. The instrumental setup allowed the determination of elements with an atomic number $(Z)$ greater than 13. The spectra were collected either from powdered samples or paint fragments.

$\mathrm{X}$-ray diffraction. The measurements were performed using an XRD-6100 Diffractometer (Shimadzu) with X-ray Cu (1.54060 $\AA$ ) radiation operating at $40 \mathrm{kV}$ and $30 \mathrm{~mA}$. The powdered samples were scanned over the $5-80^{\circ}$ range with step size of $0.02^{\circ}$ and scanning speed of $1.2^{\circ} / \mathrm{min}$.

Inductively coupled plasma-mass spectrometry. The measurements were performed by an Agilent 7500 ICP-MS. The instrument was tuned for standard robust plasma conditions and the ORS was operated in helium mode only. The instrumental operating conditions were RF power: $1550 \mathrm{~W}$; sample depth: $8.5 \mathrm{~mm}$; carrier gas: 0.80 1/min; make up gas: $0.23 \mathrm{l} / \mathrm{min}$; energy discrimination: $2 \mathrm{~V}$ and reaction gas: $\mathrm{He} 5.0 \mathrm{ml} / \mathrm{min}$.

\subsection{Sampling}

The wall painting analyses included about 50 samples which were collected from different areas: Narthex - western wall (Fig. 1a); Nave southern wall (Fig. 1b), Northern wall and painting on the pillars located in the nave interior and Iconostasis painting depicted on the stone wall that separates the nave from the sanctuary (Fig. 1c). Table 1 summarizes the representative samples and a description of the sampling positions.

Table 1

Description of the representative samples and applied analytical techniques

\begin{tabular}{|c|c|c|c|}
\hline $\begin{array}{l}\text { Part of the } \\
\text { church }\end{array}$ & Sampling position & Sample/color & Analytical technique \\
\hline \multirow{5}{*}{ Narthex } & \multicolumn{3}{|c|}{ Western wall, $2^{\text {nd }}$ zone, scene: Assumption of Virgin Mary } \\
\hline & Saint's garment & N1/blue & OM, IR \\
\hline & Saint's halo & N2/yellow & OM, IR, XRF, XRD \\
\hline & Border of the scene & $\mathrm{N} 4 /$ red & OM, IR, XRF \\
\hline & Background of the scene & N5/green & OM, IR, XRF, XRD \\
\hline \multirow{9}{*}{ Nave } & \multicolumn{3}{|l|}{ Northern wall } \\
\hline & $1^{\text {st }}$ zone, background, scene: St. Mercury & N29/green & OM,IR, XRF \\
\hline & $2^{\text {nd }}$ zone, background, scene: Torture of St. George & N11/blue & OM, IR, XRF, XRD \\
\hline & \multicolumn{3}{|l|}{ Southern wall } \\
\hline & $1^{\text {st }}$ zone, background, scene: St. Nestor & N27/green & OM, IR, XRF \\
\hline & $2^{\text {nd }}$ zone, scene: Torture of St. George, blue tunic. & N26/blue & OM, IR, XRF, XRD \\
\hline & North-eastern pillar, Saint's garment & N25/green & OM, IR, XRF, XRD \\
\hline & South-eastern pillar, glossy film & N15/dest. & IR \\
\hline & South-eastern pillar, hard glossy droplets & N16/dest & IR \\
\hline \multirow{10}{*}{ Iconostasis } & \multicolumn{3}{|l|}{ Northern side, scene: St George } \\
\hline & Saint's halo, bold area & Ik1/yellow & OM, IR, XRF \\
\hline & Saint's halo, out of the bold area & Ik2/yellow & OM, IR, XRF,XRD \\
\hline & Background of the scene & Ik6/blue & OM, IR, XRF \\
\hline & Shield & Ik7/green & OM, IR, XRF, XRD \\
\hline & Border of the scene & Ik10/red & OM, IR, XRF \\
\hline & \multicolumn{3}{|l|}{ Southern side, scene: Holy Mother } \\
\hline & Mantle of Holy Mother & Ik11/violet & OM, IR, XRF, XRD \\
\hline & Destroyed part of the left border & Ik12/red & OM, IR, XRF \\
\hline & Whitish efflorescence & Ik13/dep & IR \\
\hline
\end{tabular}



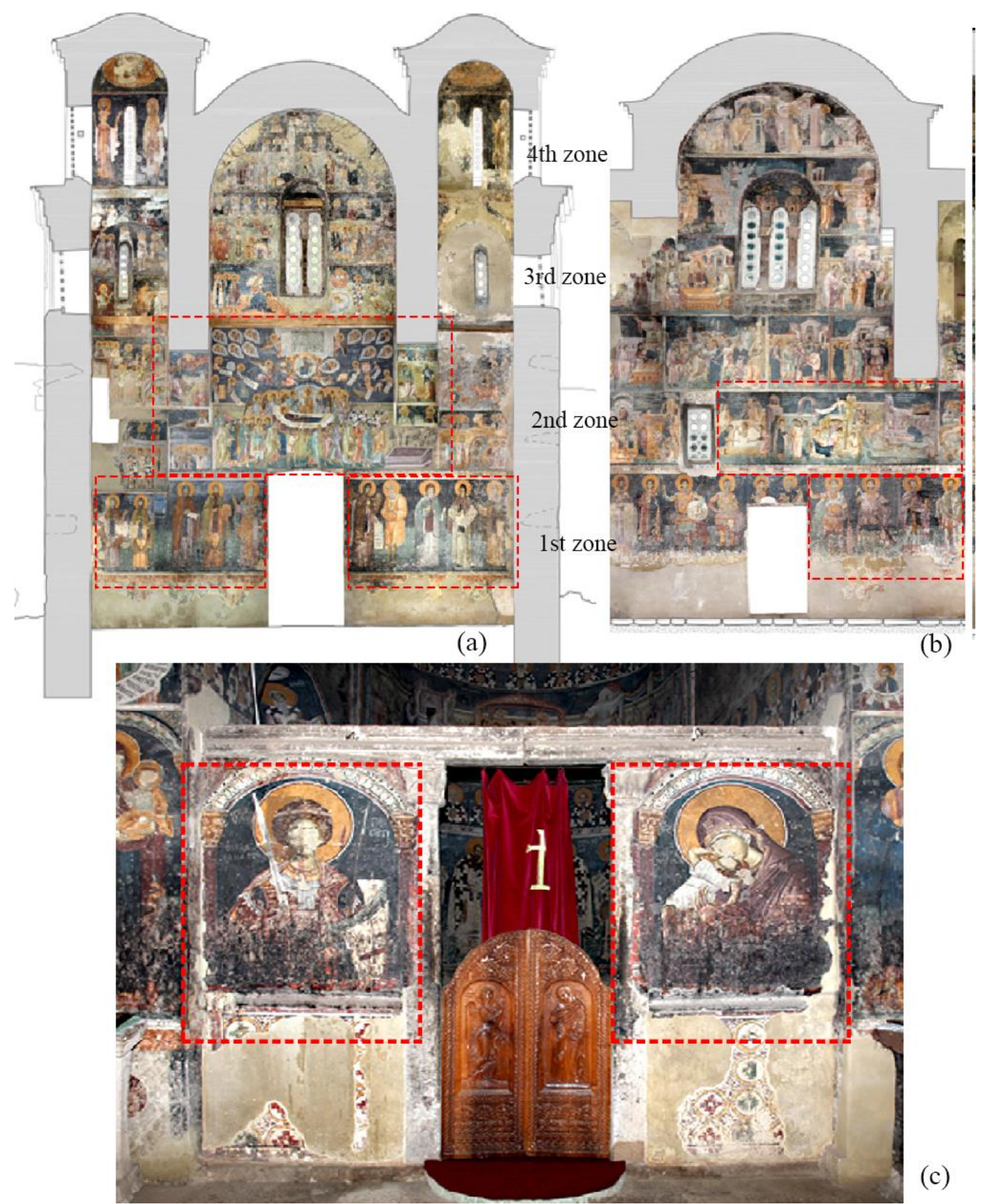

(c)

Fig. 1. The sampling areas. (a) Narthex - western wall $-1^{\text {st }}$ zone: "An assembly of Saints"; $2^{\text {nd }}$ zone: "Assumption of Virgin Mary"; (b) Nave - southern wall - $1^{\text {st }}$ zone: "St. Dimitry" and "St. Nestor"; $2^{\text {nd }}$ zone: "Torture of St. George";

(c) Iconostasis painting:"St. George" (left) and "Holy Mother with child Jesus" (right) (1a, b - reproduced with permission [2])

Representative material of various observed colors was taken by means of two micro-destructive ways: (1) collecting of powdered samples using a scalpel and (2) removing small painted fragments from damage observed on the paintings.
These fragments were embedded in polyester resin following the procedure [7] and then subjected to OM examination.

The mortar sampling strategy will be explained in the section referring to Mortar analysis. 


\section{RESULTS AND DISCUSSION}

\subsection{Microscopic examination of the paint samples}

The microscopic examination was used to establish the micro-stratigraphy, but also for general information about the raw materials and painting techniques.

Figure 2 exhibits six representative microscopic images of cross-sectioned samples from the painting in the nave, narthex and iconostasis. The general information obtained through the microscopic observation could be summarized as follows:

- The pigment bearing layers were applied on a white plaster (Fig. 2, layer - 1). Some microimages demonstrate two overlaying plasters: fine ground (intonaco) located immediately below the paint and lower rough underlying plaster (arriccio).

- The pictorial sequence contains one or two overlaying paint layers (Fig. 2, layer - 2,3) with variable thickness ranging from 25 to $50 \mu \mathrm{m}$.

- The pigment grains are united with white particles ascribed to calcium carbonate whose presence was confirmed by FTIR, XRF and XRD.

- In some samples well defined boundary between the plaster and the first paint layer can be observed (Fig. 2a-c, marked with dotted line). In other cases, the samples demonstrate penetration of the pigment grains into the plaster forming an un- defined boundary between the layers (Fig. 2d,e, marked with dotted line).

- Preliminary drawings represented by a very thin yellow layer at the base of the first paint were observed in a representative number of samples (Fig. 2f).

- Most of the samples did not show evident fluorescence under UV illumination suggesting the absence of organic binders in the pictorial sequence. The UV fluorescence was observed only in a few samples from the iconostasis painting (Fig. 3).

Regarding the painting technique, two characteristic features of the cross-sectioned samples were considered as relevant indicators of the used techniques, which are: the nature of the binding medium and the paint adherence to plaster [8-11].

The absence of organic binding medium (indicated by the lack of UV fluorescence) implies that the secco technique was not applied in the studied painting [11-13]. On other hand, the presence of calcium carbonate in the paint layers implies the use of some types of fresco techniques such as buon fresco (true fresco) which refers to painting on wet plaster with water-mixed pigments and the lime-painting technique, elsewhere also defined as mezzo-fresco, ascribed to painting on dry or almost dry plaster using pigments mixed with slaked lime $[9,11-13]$.
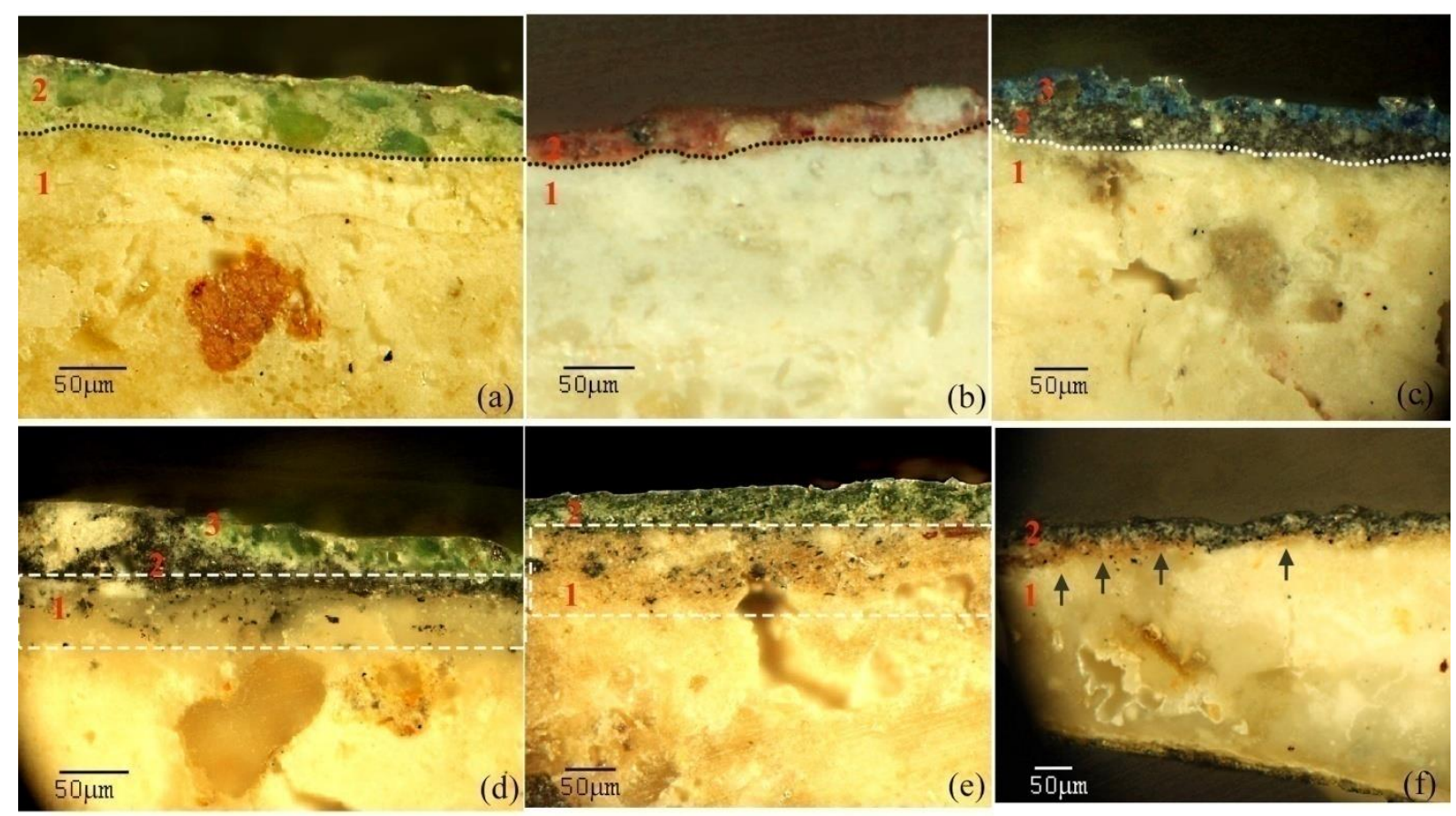

Fig. 2. Microscopic images of cross-sectioned samples (original magnification 200x): (a) N27/green; (b) N4/red; (c) N1/blue); (d) N29/green; (e) Ik7/green; (f) IK6/dark blue (arrows point to preliminary yellow drawing). 1 - plaster; 2, 3 - paint layers. Dotted lines refer to the boundary formed between the paint and plaster. 
The discrimination of these two techniques is a debatable point since both techniques are represented by lime binding medium; the corresponding micro-stratigraphic images exhibit very similar features.

The clear boundary observed between the plaster and paint layer (Fig. $2 \mathrm{a}-\mathrm{c}$ ) indicates painting on dry plaster (lime technique or mezzo-fresco) [9-11]. On other hand, the penetration of the pigment grains into the plaster, as is shown in Figure $2 \mathrm{~d}$ and e, could be ascribed to the thorough carbonation process $[8,9]$ which is typical for a painting on wet plaster (buon fresco) [8-11]. Moreover, the thin yellow layer located immediately below the superficial layer (Fig. 2f) refers to preliminary drawing, which is a characteristic feature in fresco painting [11-13].

The microscopic findings supported the hypothesis represented by the conservators and art historians, indicating the use of both lime-based techniques. The macroscopic examination was based on the visual observation of the texture of the painting surface as well as the brushstrokes effects [2]. The assumption of a fresco technique was justified considering the existence of giornates and drawing incisions in certain areas which are characteristic features of a painting on wet plaster $[11,12]$.

As previously mentioned, some samples collected from the iconostasis painting exhibited yellow-greenish fluorescence under UV light, indicating the presence of organic binders in the paint layer. Such behavior was demonstrated in the samples collected from the bold area of the Saint halo (Tab. 1, Ik1/yellow) and from certain positions of the red bordure (Tab. 1, IK12/red), as shown in Figure 3.

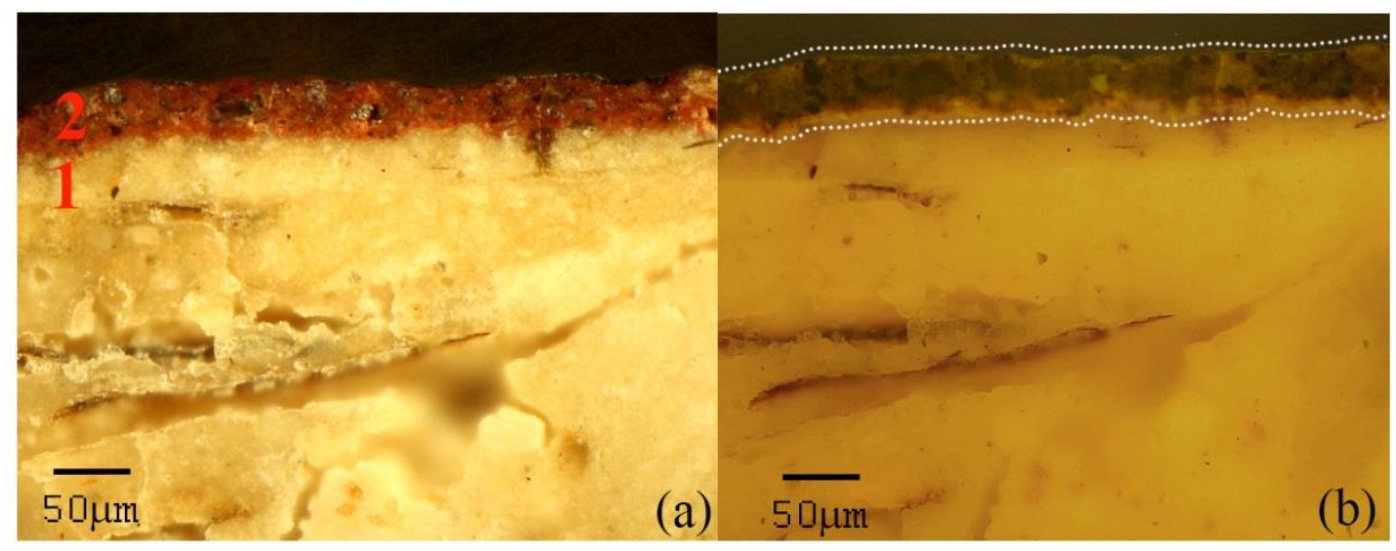

Fig. 3. Microscopic images of the cross-sectioned IK12/red sample collected from the iconostasis painting: (a) reflected light and (b) under UV light. 1 - plaster; 2 - paint layer. Marked area refers to UV fluorescence.

\subsection{Analysis of the painting ground and paint layers}

\subsubsection{Infrared spectroscopy}

According to the analytical procedure applied in this study, infrared spectroscopy was used as a first diagnostic technique in obtaining general information about the substances present in the studied painting. The results obtained from FTIR analysis were improved by the XRF and XRD results, especially in the identification of the inorganic compounds (plaster, pigments and salts).

The powdered samples of each observed paint and painting ground (plaster underneath the paint) were first subjected to FTIR-DRS analysis. In addition, the salt efflorescence which appeared either as a white thin veil or clusters of crystals on the surface of the wall painting was mainly analyzed by the use of infrared spectroscopy. Figure 4 shows representative DRS spectra of the ground (Fig. 4a) and paint layers (Fig. 4b-d) as well as spectra of the salt efflorescence (Fig. 4e, f) formed on the northern wall painting (Fig. 4, inserted image). The spectra inspection led to following assessments:

- The ground layer (Fig. 4a) is mainly composed of calcium carbonate $\left(\mathrm{CaCO}_{3}\right)$, recognized by the three active infrared fundamental modes which appeared at 1455,877 and $713 \mathrm{~cm}^{-1}$ and the weak bands at 1795 and $2510 \mathrm{~cm}^{-1}$ due to mode combinations [14-16].

- Calcium carbonate is found in all pigment bearing layers (Fig 4b-d) suggesting that the pigments are embedded in lime binding matrix. 


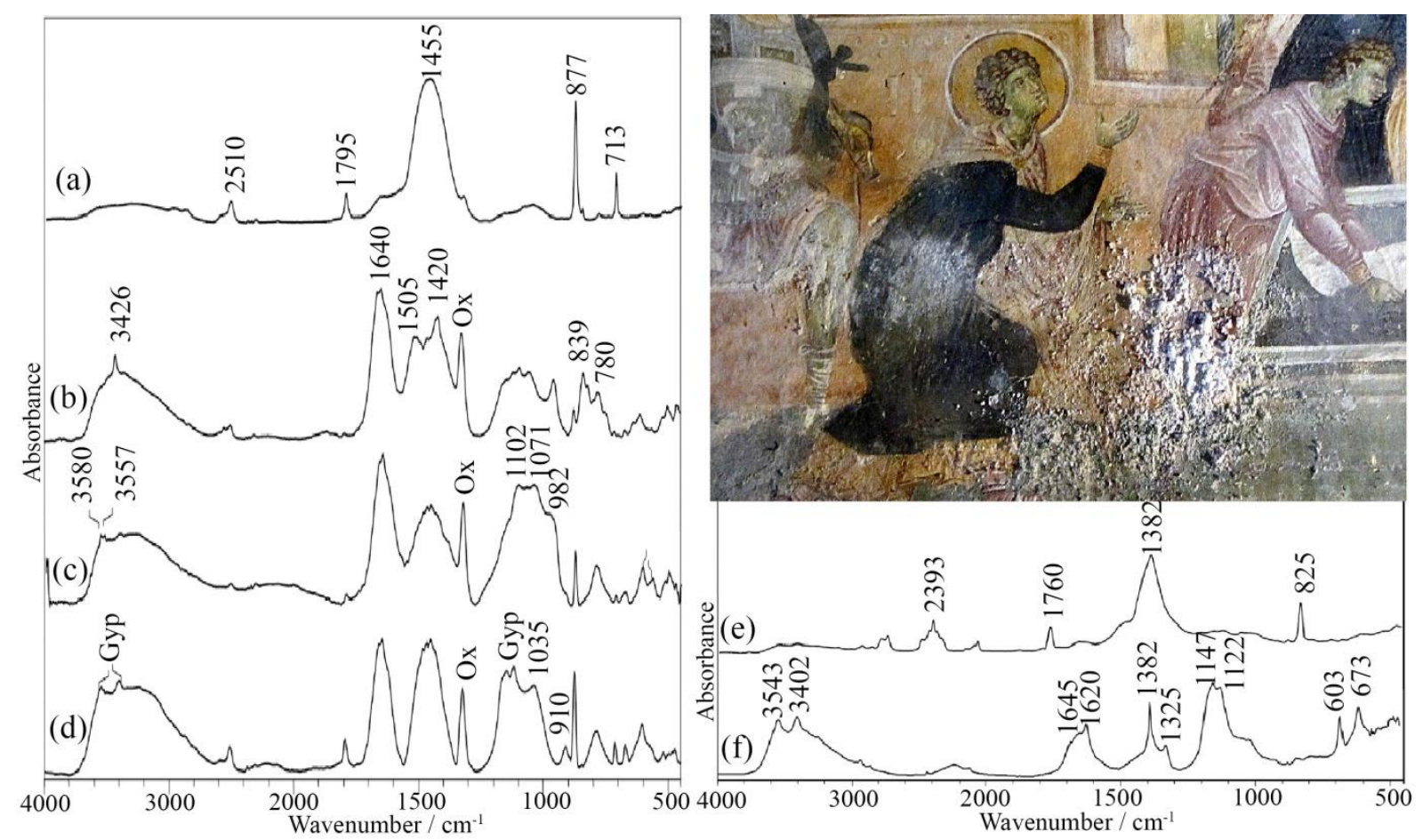

Fig. 4. Infrared spectra: (a) painting ground (intonaco) underneath the paint; (b) blue paint (N1/blue); (c) green paint (N5/green) and (d) yellow paint (N2/yellow); (e, f) salt efflorescence. Ox - oxalates, Gyp - sulfates in form of gypsum. Image: Scene of the northern wall painting threatened by salt efflorescence.

- All paint layers demonstrate the presence of salt efflorescence. The oxalate salts can be evidenced by the bands at about 1325 and $780 \mathrm{~cm}^{-1}$ [15-17]. The presence of sulfates in the form of gypsum $(3545,3404,1620,1147-1120$; 671 and $603 \mathrm{~cm}^{-1}$ ) can be observed in the yellow sample (Fig. 4d) [14-17]. The dominant band at 1640$1620 \mathrm{~cm}^{-1}$ associated with $\mathrm{HOH}$ bending vibrations in the water molecules indicates a high degree of salt hydration (Fig. 4 b-d) [17]. The salt deposits (Fig. 4e, f) were found to be composed of one type of salt such as the clusters of nitrates (Fig. 4e and inserted image) identified by the bands at 2393, 1760,1382 and $825 \mathrm{~cm}^{-1}$ or mixtures of different salts, as displayed in Figure $4 \mathrm{f}$ (mixture of sulfates, nitrates and oxalates) [14].

- The presence of azurite $\left(\mathrm{Cu}_{3}\left(\mathrm{CO}_{3}\right)_{2}(\mathrm{OH})_{2}\right)$ is strongly suggested in the blue paint (Fig.4b) considering the hydroxyl stretching vibration at $3426 \mathrm{~cm}^{-1}$ and the intense bands at 1505 and 1420 $\mathrm{cm}^{-1}$ due to the asymmetric stretching modes of the carbonate group and $839 \mathrm{~cm}^{-1}$ ascribed to the bending mode $[16,18]$.

- In the green sample (Fig. 4c), the narrow bands at 3580,3557 and $3526 \mathrm{~cm}^{-1}$ characteristic of $\mathrm{OH}$ stretching modes along with the bands in the region $1100-980 \mathrm{~cm}^{-1}$ assignable to $\mathrm{Si}-\mathrm{O}$ stretching are indicative of earth green pigments such as celadonite and glauconite $[16,19]$.
- The IR spectrum of the sample collected from the yellow paint (Fig. 4d), besides the evident presence of gypsum, shows that this paint is enriched with clay materials. This assignment could be explained by the strong absorption band at 1035 $\mathrm{cm}^{-1}$, the lower intense band at $910 \mathrm{~cm}^{-1}$ and the weak bands at $520-472 \mathrm{~cm}^{-1}$ region, tentatively attributed to kaolinite [16]. The presence of clay materials suggests that natural/earth yellow pigment was employed in this paint, such as the so called yellow ochre.

- As previously mentioned, the nature of the binding medium is important for characterization of the painting technique. The analysis of the wall painting in the "St. George" church was accomplished by means of OM and FTIR-DRS, as well as the subsequently employed analytical techniques (XRD and XRF), which indicated the presence of a lime-based binder favoring either the fresco or lime painting technique. The infrared analysis using FTIR-DRS method did not reveal significant absorption features assignable to the organic binders except in same samples from the iconostasis painting (see section 3.3).

\subsubsection{XRF analysis}

The elemental analysis of the paint layers by means of XRF measurements allowed more accurate identification of pigments. The representative 
XRF spectra displayed in Figure 5 exhibit the primary elements associated with the used pigment. Unsurprisingly, all spectra express a fraction of calcium which is mainly derived from the calcium carbonate binding matrix, but also from the $\mathrm{Ca}-$ salts (Ca-sulfate and $\mathrm{Ca}$-oxalate).The iron detected in the red and yellow paints (Fig. 5a, b) implies the presence of iron oxide $\left(\mathrm{Fe}_{2} \mathrm{O}_{3}\right)$ and iron oxide hydroxide $(\mathrm{FeOOH})$-based pigments, such as hematite and goethite, which are principal constituents in red and yellow ochre, respectively [20]. These pigments were found to be used as pure colorants but also in mixtures for obtaining particular paint hues.

It should be noted that the red and yellow paints (Tab. 1, Ik12/red and Ik1/yellow) collected from the iconostasis painting are enriched with mercury (Fig. 5c) and arsenic referring to cinnabar $(\mathrm{HgS})$ and arsenic sulfides (Fig. 5d), which could be pigments like orpiment $\left(\mathrm{As}_{2} \mathrm{~S}_{3}\right)$ or realgar $\left(\mathrm{As}_{2} \mathrm{~S}_{2}\right)$ [20]. Moreover, the Mantle of Holy Mother (Fig. 1c) is decorated with a wonderful violet color produced by mixing of hematite and azurite $\left(\mathrm{Cu}_{3}\left(\mathrm{CO}_{3}\right)_{2}(\mathrm{OH})_{2}\right)$ (Fig. 5e) which was found to be uniquely executed in this painting. The determination of iron (Fig. 5f) in the green sample corroborates the FTIR indications referring to a presence of green earth pigment (syn. terra verde, celadon green) which is a ferromagnesian silicate-based mineral [20].

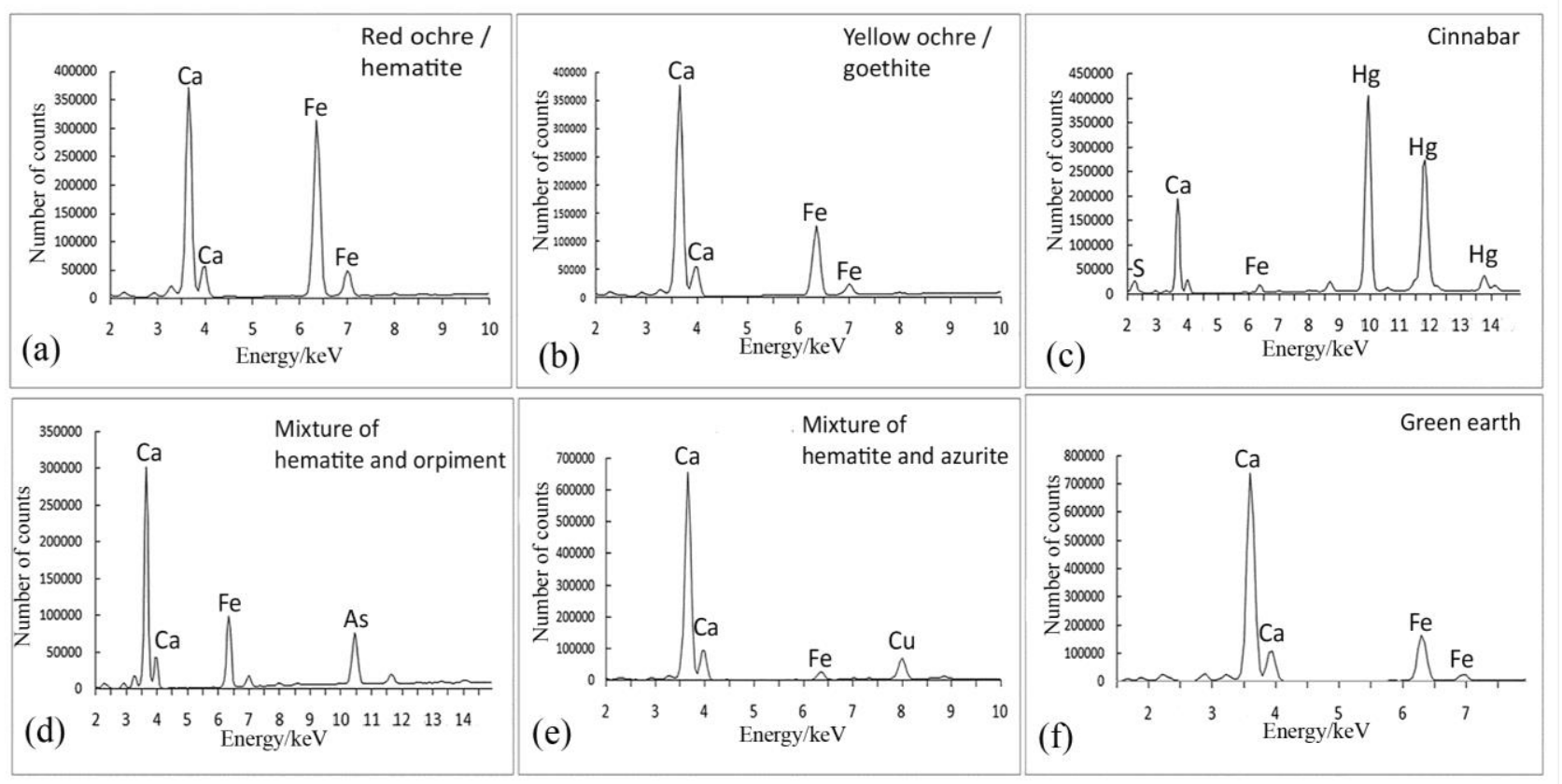

Fig. 5. Representative XRF spectra: (a) N4/red; (b) N2/yellow; (c) Ik12/red; (d) Ik1/yellow; (e) Ik11/violet; (f) N29/green

Regarding the identification of the black paint, Figure 6 shows the analytical results of the black underlying paint located below the superficial green layer in the sample N5-green. The detection of phosphorus by XRF analysis (Fig. 6a) and phosphate group determined by the bands at 1080, 1040, 960 and doublet at $605-565 \mathrm{~cm}^{-1}$ in the IR spectrum (Fig. $6 \mathrm{~b})$ suggested the presence of apatite-based minerals (Ca-phosphates group) [16, 20-22]. According to the relevant literature [20, 23-25], the inorganic component hydroxyapatite (Hap) $\left(\mathrm{Ca}_{5}\left(\mathrm{PO}_{4}\right)_{3}(\mathrm{OH})\right)$ or carbonate-Hap $\left(\mathrm{Ca}_{5}\left(\mathrm{PO}_{4}, \mathrm{CO}_{3}\right)_{3}(\mathrm{OH})\right)$ is commonly present in the carbon-based black pigments of animal origin. Hence, the detection of phosphorous and phosphate group was accepted as a reasonable indicator of the presence of bone or ivory black pigments. In addition, the presence of calcium (Fig. 6a), which is mainly derived from the $\mathrm{Ca}-$ carbonate matrix, in this case could also be attributed to the presence of the carbonate-HAp [24]. The presence of $\mathrm{Fe}$ in the black underlying paint in the sample N5-green (Fig. 6a) could be ascribed to the traces of the superficial layer containing green earth pigment, but also to the presence of black iron oxide, considering the high count number of $\mathrm{Fe}$ in the XRF spectrum.

Moreover, when the black sample was heated using a low Bunsen flame after it was placed on the platinum plate, the black color tends to disappear, indicating the presence of carbon (coal, soot) $[4,26]$. 


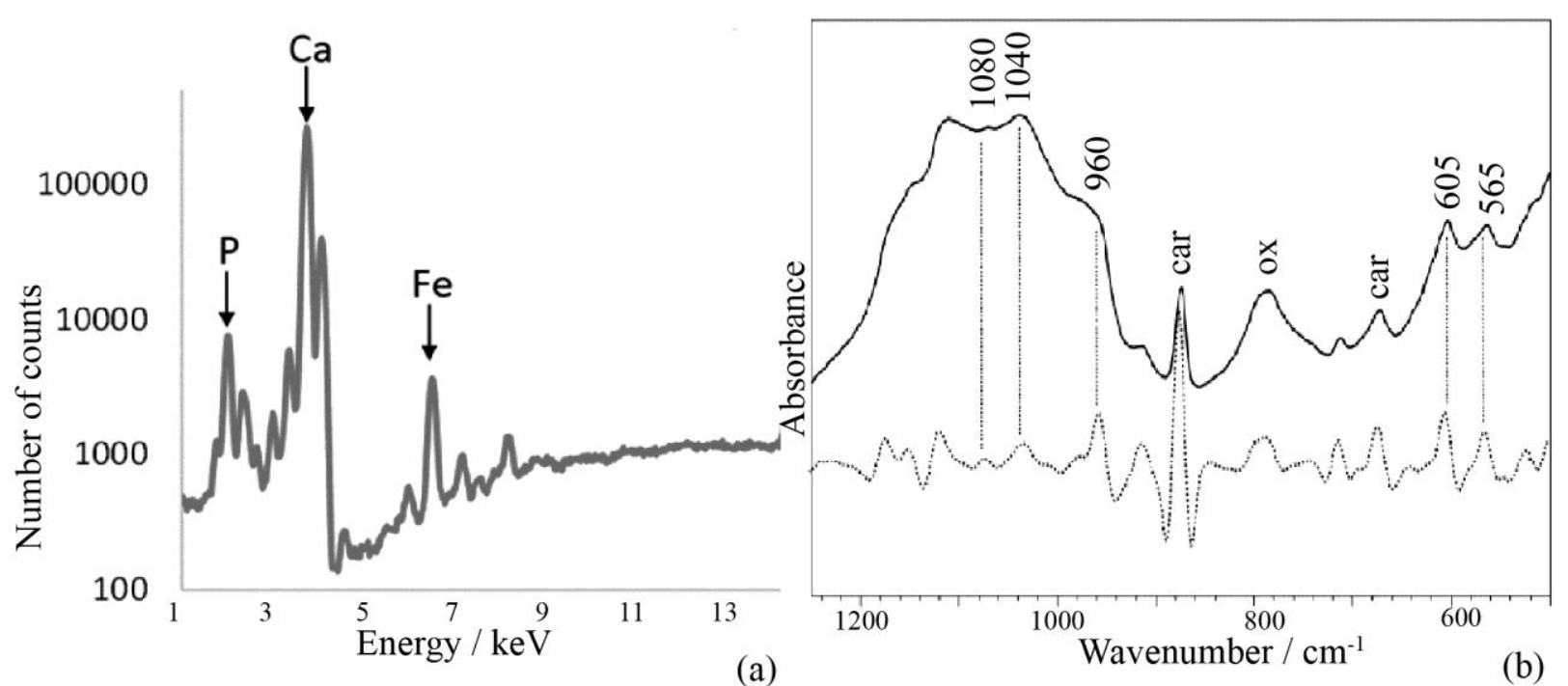

Fig. 6. Spectra of the black underlying paint located below the superficial green in the sample N5/green. (a) XRF spectrum and (b) IR spectrum and its second derivative profile (inverted curve). Car - calcium carbonate; ox - oxalate salts.

\subsubsection{XRD analysis}

Few representative samples associated to the yellow, blue and green paint were subjected to XRD analysis (Fig. 7). Mineral identification was achieved by detecting a series of peaks with characteristic $d$ values and by using the ICDD database (PDF-2 Release 2011).

Summarizing the results from the diffraction pattern analysis (Tab. 2) the following statements could be noted:

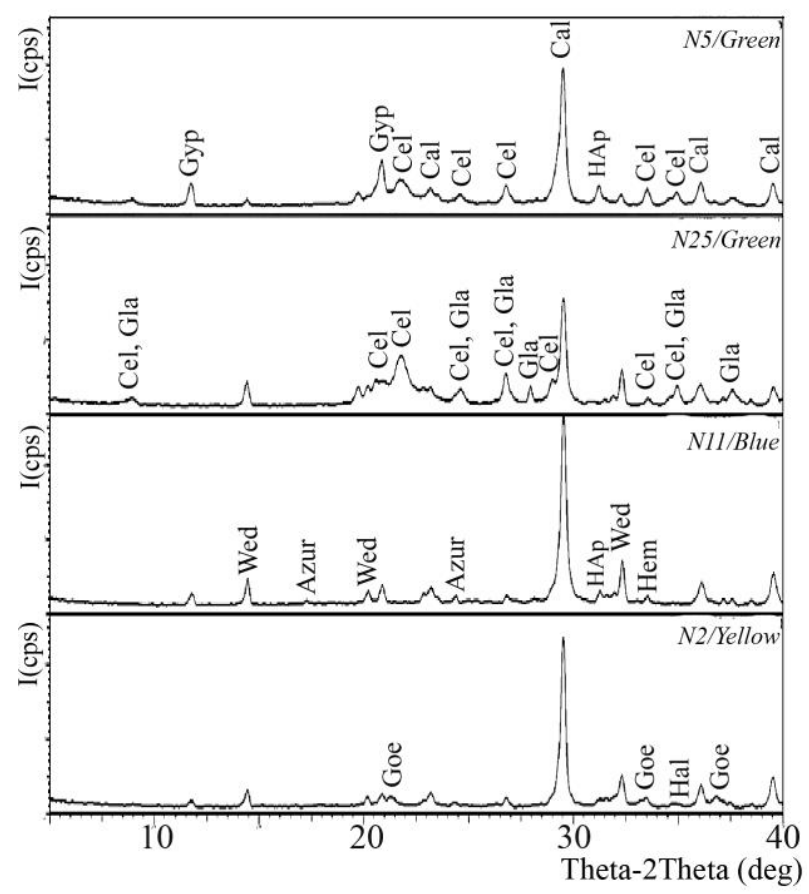

- All pigment bearing layers (green, blue and yellow) contain calcite which derives from the lime binding matrix in the paint.

- The artistic palette is composed of mineral pigments: goethite, hematite, azurite and two species of earth green pigments which are celadonite and glauconite. The detection of carbonated hydroxy-apatite supported the XRF and FTIR results, indicating the presence of black pigment of animal origin (bone or ivory black).

- The majority of salt efflorescence is composed of gypsum and weddellite, with a fraction of halite being determined in some samples.

Fig. 7. XRD patterns of representative green, blue and yellow. Cal - calcite (PDF: 5-0586); Cel - ferroceladonite (PDF: 501580); Gla - glauconite (PDF: 3-191); Azur - azurite (PDF: 20153); Goe - goethite (card: 3-0249); Hem - hematite (PDF: 330664); HAp - carbonate hydroxyl-apatite (PDF: 1-75-3728 ); Gyp - gypsum (PDF: 36-0432); Wed - weddelite (PDF: 40702); Hal - halite (PDF: 2-0818). 
Table 2

Summary of results obtained by XRD analysis

\begin{tabular}{lccc|cccc|ccc}
\hline \hline \multirow{2}{*}{$\begin{array}{l}\text { Representative } \\
\text { samples }\end{array}$} & \multicolumn{3}{c|}{ Binder } & \multicolumn{4}{c|}{ Pigments } & \multicolumn{3}{c}{ Salt efflorescence } \\
\cline { 2 - 12 } & Cal & Cel & Gla & Azur & Hem & Goe & HAp & Gyp & Wed & Hal \\
\hline N5/green & + & + & & & & & + & + & + & \\
N25/green & + & + & + & & + & & & & + & \\
N11/blue & + & & & + & & & + & + & + & \\
N2/yellow & + & & & & & + & & + & + & + \\
\hline \hline
\end{tabular}

\subsection{Analysis of the painting deterioration}

In terms of the conservation-restoration requirements different phenomena were examined: salt efflorescence occurred over the entire wall painting, a glossy thin film and hard glossy droplets mostly appeared on the pillar's painting and the various alterations observed on the iconostasis painting.

The most important risk factor in painting decay was found to be the salt efflorescence. The process of salt growth is believed to be related to the increased moisture content in the wall and the microclimatic variations [2]. The analysis performed by FTIR (Fig. 4) and XRD (Fig. 7, Tab. 2) demonstrated that salt efflorescence mainly appears in the form of sulfates and oxalates, but also as nitrates and chlorides. The cycle of crystallization, dissolution and re-crystallization of the water soluble salts have caused a lack of cohesion in the pigment-bearing layers, crumbling, flaking and losing paint.

The presence of glossy film and hard glossy droplets on the pillar's painting surface (nearby the sanctuary) was found to be uncommon in comparison to the majority of the wall painting (Fig. 8, inserted image). The micro-IR analysis (Fig. 8a) of the glossy droplets indicated presence of lipidic matter such as wax considering the absorptions at 2919-2848 $\mathrm{cm}^{-1}(\mathrm{C}-\mathrm{H})$; $1734 \mathrm{~cm}^{-1}$ (ester $\left.\mathrm{C}=\mathrm{O}\right)$; $1468,1379 \mathrm{~cm}^{-1}(\mathrm{C}-\mathrm{H})$ and $1173 \mathrm{~cm}^{-1}$ (C-O-C). The spectrum of the material scraped from the glossy surface (Fig. 8b) shows strong absorptions associated with the inorganic substances which cover the lower intense bands attributable to the organic matter. However, the separation of the multiple bands observed in the second derivative profile of the original spectrum revealed spectral features comparable with the previous spectrum assigned to wax (Fig. 8a).

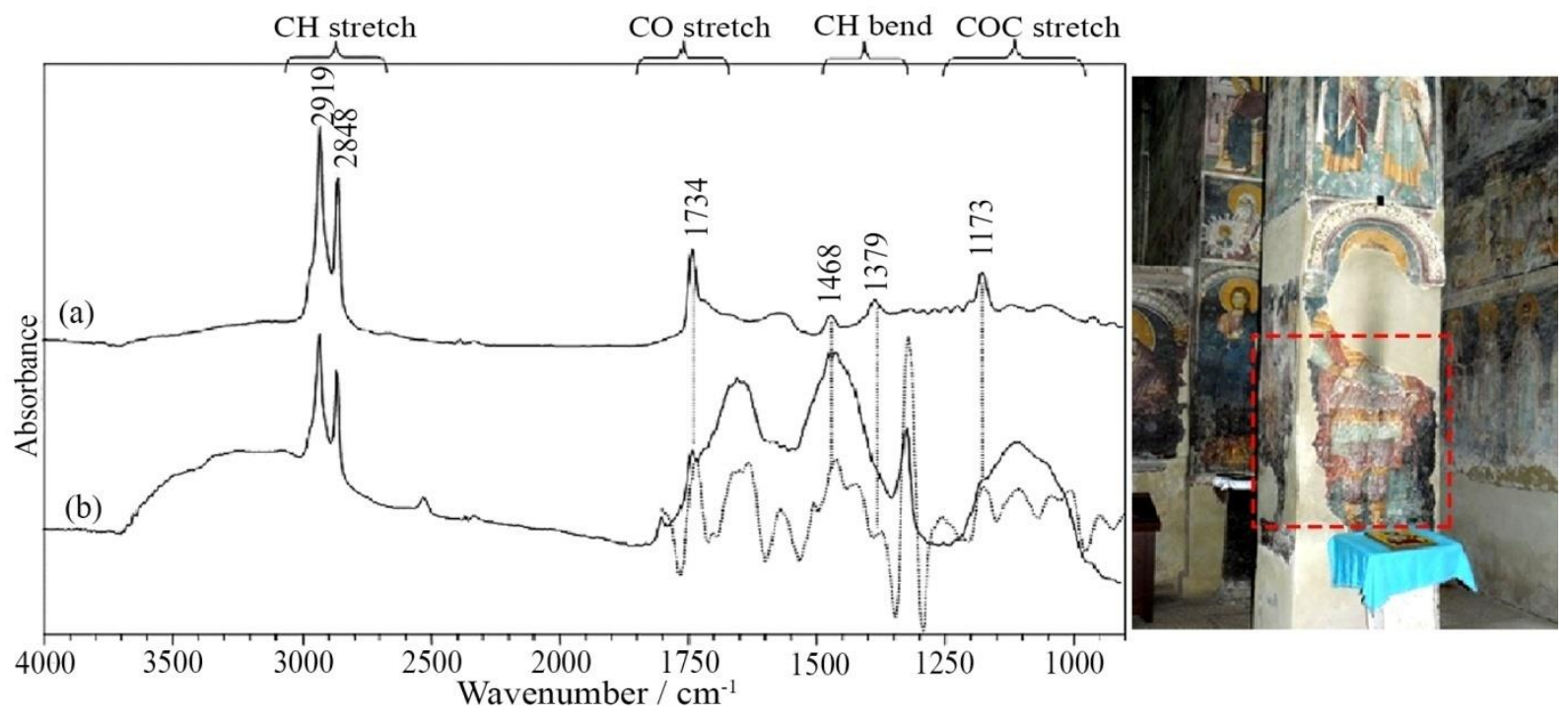

Fig. 8. Micro-IR spectra of samples collected from the pillar's painting.

(a) hard glossy droplets; (b) glossy film and its second derivative profile in the $1800-900 \mathrm{~cm}^{-1}$ region (inverted curve).

Moreover, the visual in situ observation of the studied glossy film in terms of physical properties, softness and solubility in chloroform corrobo- rate the IR indications of the presence of waxy material. It is known that the wax has been traditionally employed for the superficial treatment of the 
paintings in order to protect and consolidate the paint layers [12, 13]. However, in this case, we assume that the presence of the waxy film is a result of the long-term exposure of the painting to the condensation of candle smoke and over time has also penetrated into the painting layers.

The most obvious alterations were observed on the iconostasis painting: (1) red bordure of the scenes, where two different red paints exist (Fig. 9); (2) bold area that covers about $15 \times 20 \mathrm{~cm}$ of the pictorial surface which seems to be deliberately left during previous interventions (Fig. 10); (3) whitish tiny lumps appeared on the pictorial surface (Fig. 11) and (4) blackening on the painting.

Macro- and microscopic observations of the red bordure of the scenes revealed the existence of two different red paints (deep and light red). Most of the bordure is painted with the deep red, which according to the XRF and FTIR results is composed of hematite and calcite. In some parts of the bordure, there is a light red paint containing cinnabar, which was identified by the XRF analysis (Fig. 5), and an organic binder suggested by the OM (Fig. 3) and FTIR-DRS analysis. The corresponding samples were subjected to further exami- nation by the use of micro-IR. The micro-IR analysis of the light red is represented by the sample Ik12/red (Fig. 9). The resolution improvement and separation of the overlapping bands in the absorption spectrum was achieved by the use of derivative spectroscopy [21].

The resolution enhancement provided by the second derivative manipulation of the original spectrum (Fig. 9) demonstrates distinct bands in the region characteristic for carbonyl stretching vibrations. The band at $1740 \mathrm{~cm}^{-1}$ attributable to ester carbonyl bonds together with the band at $1175 \mathrm{~cm}^{-1}$ and the lower intensity bands at 1260 and $1110 \mathrm{~cm}^{-1}$ (ester triplet) associated with $\mathrm{C}-\mathrm{O}$ stretches are indicative of the presence of drying oil [17, 27-30].The broadening and shifting of the ester carbonyl band to lower frequency could be related to other carbonyl products (acids, ketones, aldehydes, lactones, anhydrides or conjugated carbonyl groups) formed by the aging process [17, 27-30]. A detailed overview of the changes in the infrared spectra associated with the oil aging and the influence of the pigments on the aging mechanism is reported by Weerd et al. [27].

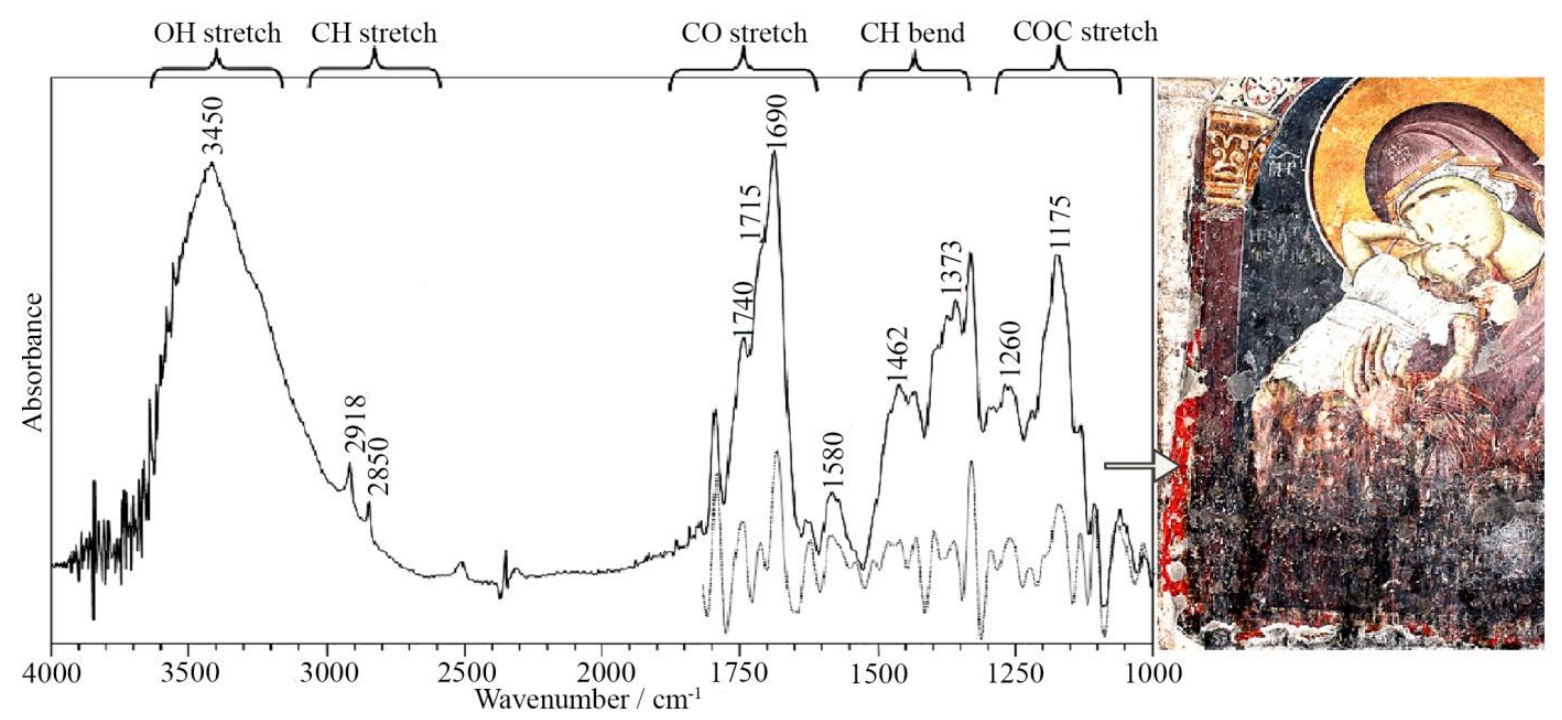

Fig. 9. Micro-IR spectrum of red paint (Ik12/red) and its second derivative profile (inverted curve). The image presents the sampling region.

Thus, the formation of carboxylic acids as products of hydrolysis of the triglycerides could be assumed through the resolved band at $1715 \mathrm{~cm}^{-1}$, which appears as a shoulder in the original spectrum. In addition, the appearance of an intense absorption band at $3450 \mathrm{~cm}^{-1}$ is indicative of the formation of alcohol and/or hydroperoxide, both of which are products of oxidation and polymerization during the aging process of oils [27, 28].
The presence of oil-based red paint in the bordures of both scenes in the iconostasis painting is indicative of some posterior retouches. In other words, the overall analysis of the wall painting did not give any indication of the presence of oil or some other organic binder, except in this region of the iconostasis painting. This finding led to an assumption that this performance is an act of restoration work rather than an original painting. 
Figure 10 shows the spectrum of the sample (IK1/yellow) collected from the bold superficial layer. The prominent absorption peaks at 3250 and $1645 \mathrm{~cm}^{-1}$ ascribed to $\mathrm{OH}$ vibrations and the strong absorption in the $1100-1030 \mathrm{~cm}^{-1}$ region, which is typical for $\mathrm{C}-\mathrm{O}$ stretching vibrations within polysaccharides [17, 31-35], suggest the presence of some plant gums such as Arabic gum (Fig. 10b) or cellulose derivatives. An explanation of the polysaccharide content in the studied painting is not straight-forward since there are many possibilities for its origin. One of the possible explanations is the use of saccharide-based products as a coating layer in order to protect the painting.
However, according to the XRF analysis (Fig. 5d), the bold yellow contains an As-based pigment which is absent in the other part of the Saint's halo (Fig. 10, inserted image). This finding also contributes to the hypothesis of possible intervention or an act of restoration.

The inspection of the spectrum associated with the whitish tiny lumps on the iconostasis painting (Fig. 11) suggested the existence of carboxylate salts, such as lactates. This can be explained by the strong absorption at $1590 \mathrm{~cm}^{-1}$, which is indicative of the symmetric stretching vibration of $\mathrm{COO}^{-}$groups $[28,29]$ and the spectrum matching with the reference spectra of $\mathrm{Ca}-$ lactate and Fe-lactate, as displayed in Figure 11.

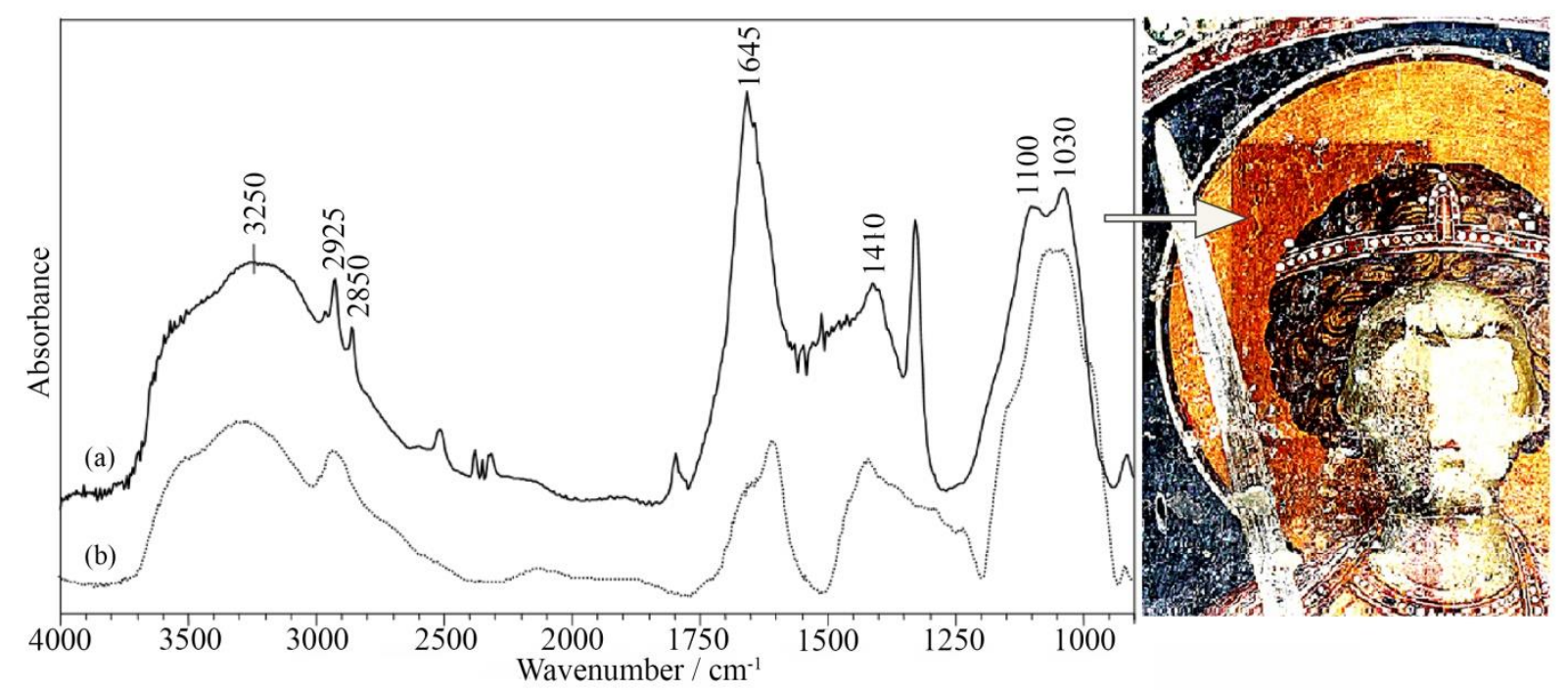

Fig. 10. (a) Representative micro-IR spectrum of the material collected from the bold superficial layer; and (b) Reference spectrum of Arabic gum. The image presents the sampling region.

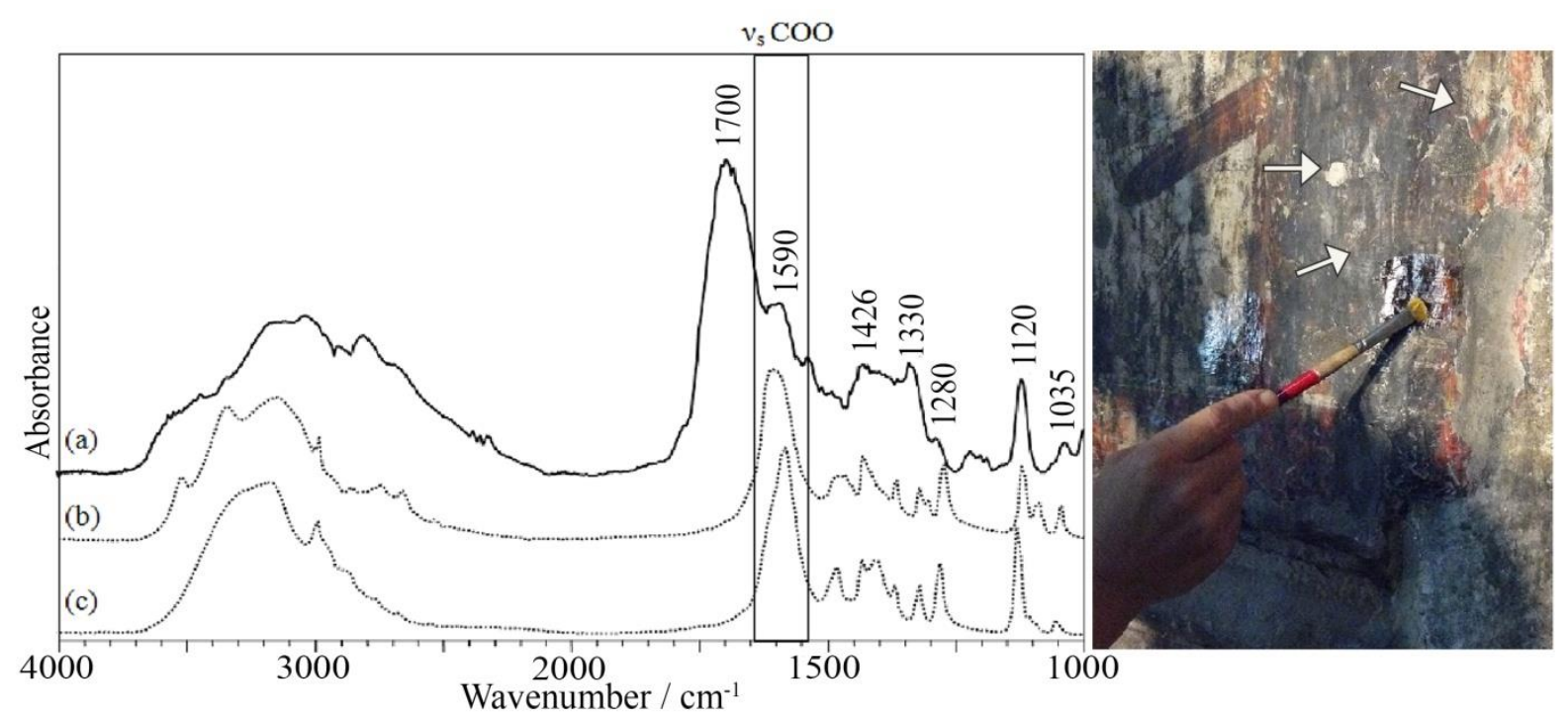

Fig. 11. (a) Micro-IR spectrum of the whitish efflorescence formed in the iconostasis painting; (b) Reference spectrum of Ca-lactate; (c) Reference spectrum of Fe-lactate. 
It was assumed that the formation of carboxylates of simple organic acids such as the lactates was caused by the application of liquid soaps used as cleaning agents during the previous conservation treatments of the pictorial surface [3]. It is well known that oleate-based soaps are frequently used cleaning agents in conservation practice. Therefore, the soaps which remained in the pictorial surface due to incomplete rinsing have most likely been degraded and interact with the metals contained in the pigments. The strong absorption observed at $1700 \mathrm{~cm}^{-1}$ suggests the presence of other carbonyl compounds formed during degradation.

The infrared analysis of the material collected from the blackened areas observed on the iconostasis painting (see Fig. 1c, lower parts of the scene, and Figure 9, inserted image) did not provide satisfactory information and therefore there is a need for further investigation by the use of other analytical methods. In addition, the in situ cleaning tests using different organic solvents also failed to give satisfactory results. So far, we can only say that the black appearance is most probably a result of high thermal influence (candle flame or fire) which has caused extreme alterations of the painting materials and possibly a loss of the original painting in the affected regions.

\subsection{Mortar analysis}

The mortar analysis was required in order to enable the preparation of compatible conservation mortars with similar chemical compositions and physical-mechanical properties to the original building material. The samples were extracted from different depths of the multi-coated external walls in order to obtain representative material of each subsequent layer. Schematic representation of the distinct layers recognized in the external walls is displayed in Figure 12 and short descriptions of the studied mortars are outlined in Table 3.

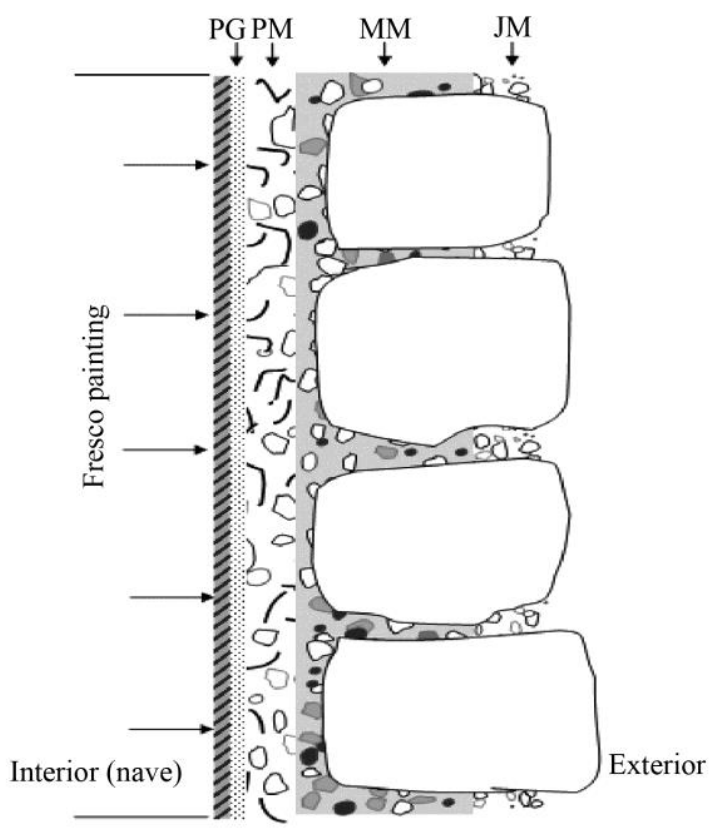

Fig. 12. Schematic representation of the distinct layers recognized in the external walls. PG - painting ground, PM plastering mortar, $\mathrm{MM}$ - masonry mortar, JM - joint mortar.

Table 3

Short description of the mortar samples

\begin{tabular}{|c|c|c|c|}
\hline & Subsequent layers & Abbr. & Description \\
\hline \multirow{2}{*}{$\begin{array}{l}\text { Inner } \\
\text { mortars }\end{array}$} & Painting ground (intonaco) & PG & $\begin{array}{l}\text { Thin and fine finishing layer on which the painting } \\
\text { was drawn }\end{array}$ \\
\hline & Plastering mortar & PM & $\begin{array}{l}\text { Rough plaster containing chopped straw, located } \\
\text { under the final ground }\end{array}$ \\
\hline \multirow{2}{*}{$\begin{array}{l}\text { External } \\
\text { mortars }\end{array}$} & Masonry mortar & MM & $\begin{array}{l}\text { Coarse rendering mortar connected with the inner } \\
\text { plaster }\end{array}$ \\
\hline & Joint mortar & $\mathrm{JM}$ & $\begin{array}{l}\text { Facade finishing mortar used for the joints between } \\
\text { the stone blocks }\end{array}$ \\
\hline
\end{tabular}

\subsubsection{XRD analysis of the mortars}

Figure 13 displays diffractograms of representative samples of the mortars PG, PM, MM and JM. The XRD results indicated the presence of calcite in all of the studied mortars. All samples except PG demonstrate greater or lower amounts of siliceous aggregates composed of quartz followed by feldspar (albite, anorthite), clay minerals with a pronounced amount of montmorillonitebeidellite series and clinochlore as an accessory mineral. The painting ground is essentially composed of calcite (Fig. 13, PG). The plaster marked as PM underneath the painting ground is composed 
mostly of calcite and siliceous aggregate (Fig. 13, PM), but also a large amount of chopped straw that was determined by macro- and microscopic observations. However, the XRD patterns of the studied samples (PM, MM and JM) indicated that different mix proportions in terms of binder/aggregate (B:A) ratios were used in mortar production.

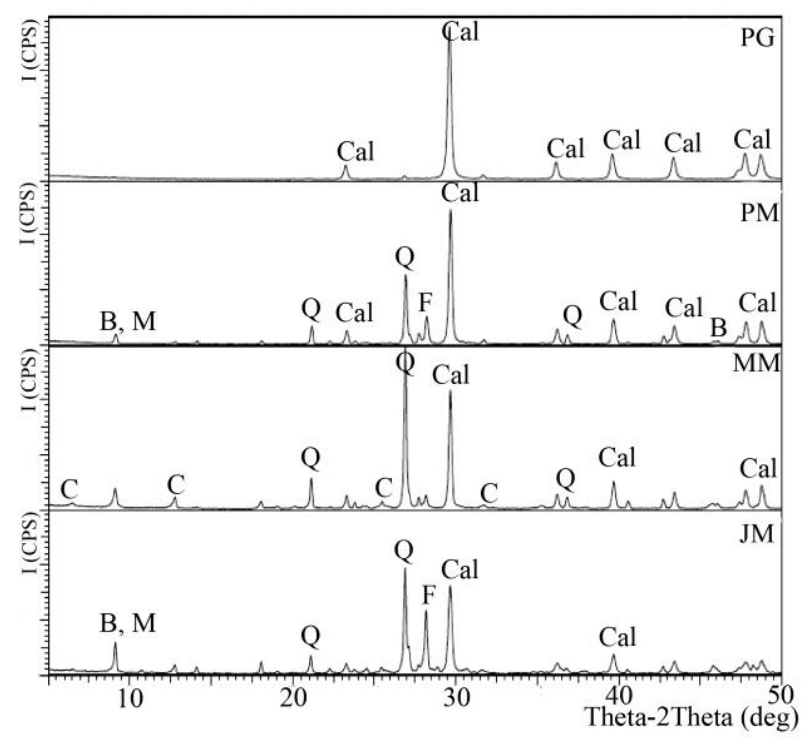

Fig. 13. XRD patterns of representative samples of the inner plasters (PG and PM) and the external mortars (MM and JM). Cal - calcite (ICDD PDF 2-629); Q - quartz (ICDD PDF 2471); F - Na-Feldspar (ICDD PDF 1-70-3752; 41-1481); M montmorillonite (ICDD PDF 60-321); B - beidellite (ICDD PDF 58-2021); C - clinoclore (ICDD PDF 2-111).

\subsubsection{Chemical analysis and determination of the binder/aggregate ratio}

The initial binder/aggregate ratio $(\mathrm{B}: \mathrm{A})$ is one of the most important attributes of the mortars. Therefore, a very important step in the analytical procedure is the mortar disintegration and separation of the constituents. The relevant literature [36-40] reports various hydrochloric acid-based treatments for binder/aggregate separation differing in the experimental conditions in terms of acid concentration, duration of the acid attack as well as temperature. In this study, the binder/aggregate separation was achieved by acid attack with dilute $\mathrm{HCl}(1: 4 v / v, 37 \% \mathrm{HCl}$ in water) and digestion in a boiling water bath for 30 minutes. This wet separation method was considered appropriate since the aggregates of the studied mortars have a mainly siliceous nature without evident calcareous content, such as marble or limestone, which is susceptible to acid dissolution. The acidic soluble fraction (SF) that is comparable with the binder content of the mortar was subjected to ICPMS quantitative measurements. The acid insoluble residue (IR) was assumed to represent the total aggregate content (A) in the mortar [38, 39].

All mortar samples were also subjected to thermal treatment using laboratory ovens in order to determine the loss on ignition at $1000^{\circ} \mathrm{C}(\mathrm{LI})$ related to the $\mathrm{CO}_{2}$ released due to calcinations of the carbonates $[37,38,40]$. Table 4 summarizes the results obtained by the entire analysis and Figure 14 represents the concentration of the trace elements.

Ta ble 4

The summary of results obtained from the chemical analysis of the mortar samples. The percentages $(w / w \%)$ relate to original dry mortar.

\begin{tabular}{|c|c|c|c|c|c|c|c|c|}
\hline \multirow{2}{*}{ Mortar layer } & \multirow{2}{*}{$\begin{array}{c}\text { LI } \\
(\%)\end{array}$} & \multicolumn{6}{|c|}{$\begin{array}{l}\text { Acid soluble fraction (SF) } \\
(\%)\end{array}$} & \multirow{2}{*}{$\begin{array}{c}\text { Insloluble } \\
\text { residue (IR) } \\
(\%)\end{array}$} \\
\hline & & $\mathrm{CaO}$ & $\mathrm{MgO}$ & $\mathrm{Al}_{2} \mathrm{O}_{3}$ & $\mathrm{Fe}_{2} \mathrm{O}_{3}$ & $\mathrm{Na}_{2} \mathrm{O}$ & $\mathrm{K}_{2} \mathrm{O}$ & \\
\hline $\mathrm{PM}$ & 29.40 & 35.80 & 0.70 & 0.42 & 0.03 & 0.09 & 0.07 & 32.70 \\
\hline MM & 13.50 & 16.10 & 0.40 & 1.29 & 0.23 & 0.14 & 0.14 & 67.77 \\
\hline $\mathrm{JM}$ & 18.20 & 22.50 & 0.50 & 1.22 & 0.26 & 0.11 & 0.10 & 56.50 \\
\hline
\end{tabular}

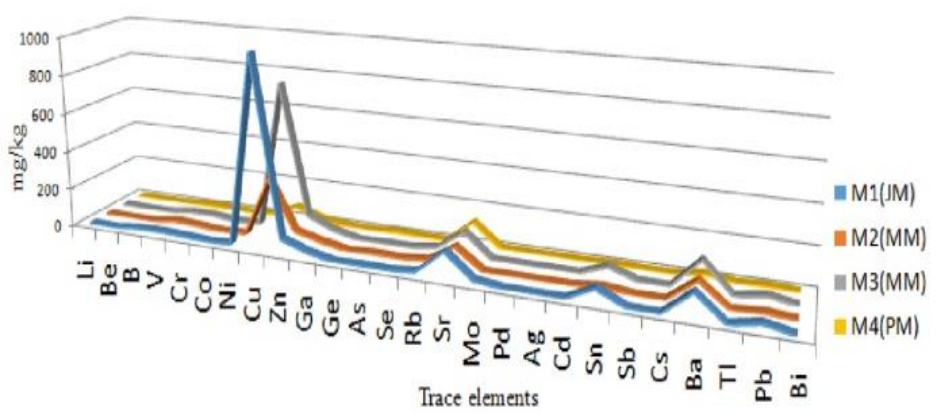

Fig. 14. Concentrations of the trace elements in the studied mortars. 
The results of the complete chemical analysis accomplished by ICP-MC corroborate the XRD results revealing high calcium and low magnesium content establishing the use of calcitic lime. The considerable amounts of $\mathrm{Al}_{2} \mathrm{O}_{3}$ and $\mathrm{Fe}_{2} \mathrm{O}_{3}$ indicated the hydraulic property of the mortars. The trace element concentrations showed comparable proportions in all of the studied samples, revealing that the raw materials originated from the same geological quarry.

The estimation of the initial mix ratio (Table 5) was achieved using the equation presented below. This equation for calculating the initial weight percentages of raw materials is comparable with those reported in the relevant literature [38, 39].

$$
\begin{gathered}
B: A=\left(\% \mathrm{CaO} \cdot \frac{M\left(\mathrm{Ca}(\mathrm{OH})_{2}\right)}{M(\mathrm{CaO})}\right): \% I R= \\
=B_{0}:\left(100-B_{0}\right)
\end{gathered}
$$

The initial lime binder $\left(B_{0}\right)$ represents the fraction of hydrated lime $\left(\% \mathrm{Ca}(\mathrm{OH})_{2}\right)$ in the initial mortar mixtures. This was calculated taking into account the $\mathrm{CaO}$ determined in the acid soluble fraction. The fraction of aggregate $(A)$ in the initial mixtures was obtained by subtracting of $B_{0}$ from the total content $(100 \%)$, assuming that total content is a sum of hydrated lime and aggregate.

In Table 5, the carbonated binder $\left(B_{\text {carb }}\right)$ represents $\% \mathrm{CaCO}_{3}$ in the dry mortar which was calculated by $\mathrm{CO}_{2}$ determined as LI (Table 4 ).

\section{Table 5}

The approximate weight percentages of the carbonated lime $\left(B_{\text {carb }}\right)$ in dry mortars and the initial constituents, hydrated lime $\left(B_{0}\right)$ and aggregate $(A)$, followed by $B: A$ ratio

\begin{tabular}{ccccc}
\hline \hline $\begin{array}{c}\text { Mortar } \\
\text { layer }\end{array}$ & $\% B_{\text {carb }}$ & $\% B_{0}$ & $\% A$ & $B: A$ \\
\hline PM & 66.8 & 59.1 & 40.9 & $1: 0.7$ \\
MM & 30.7 & 23.9 & 76.1 & $1: 3.2$ \\
JM & 41.4 & 34.5 & 65.5 & $1: 1.9$ \\
\hline \hline
\end{tabular}

\subsubsection{Grain size distribution of dry mortars}

The grain size analysis was performed by means of sieving the carefully crushed samples through a system of different sieves and weighing each separated fraction [41].

The size grading curves and weight percentage of the individual fraction retained on the sieves are displayed in Figure 15.

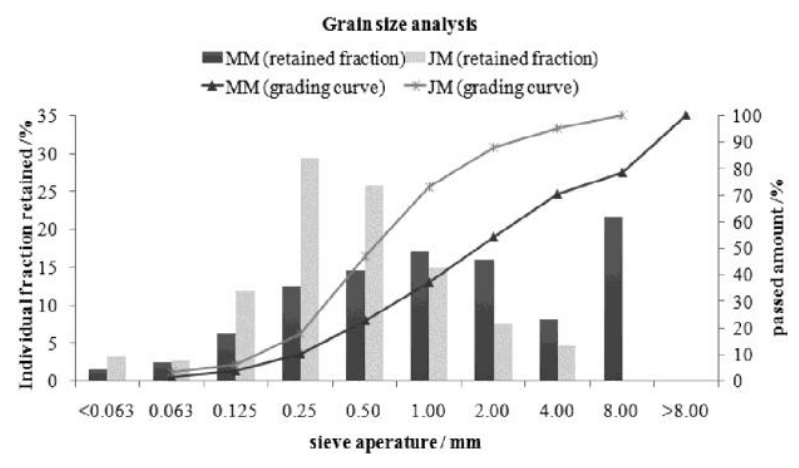

Fig. 15. Size grading curves and weight percentages of the individual fractions showed with bars

The granulometric analysis of the masonry mortar (MM) shows that about $45 \%$ of the total mass results from grains with a size larger than $2 \mathrm{~mm}$, indicating the presence of gravel [42]. The sieve analysis of the joint mortar (JM) revealed that the most abundant fractions (about 70\% of total weight) are composed of grains with a size that generally ranges from 0.125 to $1 \mathrm{~mm}$. About $12 \%$ are grains with sizes larger than $2 \mathrm{~mm}$ and about $18 \%$ are fine grained sand (grain size smaller than $0.125 \mathrm{~mm}$ ).

The results obtained contributed to the preparation of conservation mortars with granulometric features similar to the original mortars.

\section{CONCLUSION}

The wall painting in the "St. George" church in Staro Nagoričane was examined in order to characterize the materials and techniques used by the artists, but also to reveal the presence of other materials due to posterior interventions and degradation process. The use of complementary techniques allowed the micro-stratigraphy, the artistic palette (pigments) and binders that represent the painting technique used to be established (Tab. 6).

The unambiguous identification of the inorganic substances was achieved by the use of XRF and XRD analysis. The combined use of different techniques, OM, FTIR, XRF and XRD allowed unequivocal determination of the lime-based binder favoring the fresco and mezzo-fresco (limepainting). The achievement of the infrared spectroscopic techniques, DRS and micro-FTIR, was demonstrated in the determination of various compounds (inorganic and organic) encountered in the micro-samples, without the need for specific sample preparation. The use of derivative spectroscopy was found to be unavoidable in the determination of the organic compounds in order to minimize the interference of the strong IR signals associated to the abundant inorganic compounds (lime, pigments and salt efflorescence). 
Table 6

Summary of the analytical results

\begin{tabular}{|c|c|c|}
\hline $\begin{array}{l}\text { Analyzed area / Anal. } \\
\text { Techn. }\end{array}$ & $\begin{array}{c}\text { Analytical findings } \\
\text { in the wall painting: } \\
\text { Nave, Narthex and Iconostasis }\end{array}$ & $\begin{array}{l}\text { Additional findings } \\
\text { in the iconostasis painting }\end{array}$ \\
\hline Stratigraphy / OM & $\begin{array}{l}\text { Painting ground (intonaco) overlayed with one or } \\
\text { two paint layers. }\end{array}$ & $\begin{array}{l}\text { Some samples exhibit UV } \\
\text { fluorescence }\end{array}$ \\
\hline $\begin{array}{l}\text { Pigments / } \\
\text { DRS, XRF, XRD }\end{array}$ & $\begin{array}{l}\text { Hematite, goethite, azurite, green earths } \\
\text { (celadonite, glauconite), lime white and bone or } \\
\text { ivory black }\end{array}$ & Cinnabar and orpiment \\
\hline $\begin{array}{l}\text { Painting technique / } \\
\text { DRS, XRF, XRD }\end{array}$ & $\begin{array}{l}\text { Binder: Ca-carbonate, combination of fresco and } \\
\text { mezzo-fresco }\end{array}$ & Oil based red paint \\
\hline $\begin{array}{l}\text { Painting alteration / } \\
\text { DRS, micro-IR,XRF, } \\
\text { XRD }\end{array}$ & $\begin{array}{l}\text { Salt efflorescence: oxalates, sulfates, nitrates, } \\
\text { chlorides. } \\
\text { Other: waxy film derived from the candles smoke }\end{array}$ & $\begin{array}{l}\text { Presence of polysaccharide based } \\
\text { materials (not specified) and carbonyl } \\
\text { compounds (lactates, acids etc.). }\end{array}$ \\
\hline
\end{tabular}

The overall analysis revealed that certain areas of the iconostasis painting, recognizable by the naked eye, contain materials which are not present in other parts of the painting (Tab. 6). Based on these findings, it is reasonable to assume that some posterior interventions (retouches, coatings) or restoration works have been executed on the iconostasis painting.

The long-term exposure of the painting to variable ambient conditions has induced the occurrence of salt efflorescence, deposits of waxy material derived from candle smoke and products resulting from the presence of materials susceptible to degradation process like denaturalization, hydrolysis and similar reactions.

Regarding the mortar analyses, the presence of different lime-based mortars was found in the multi-coated walls of the church. This indication was obtained considering the chemical composition of the mortars, mix ratio of the raw materials (B:A) and granulometric composition.

We believe that this study gave considerable information about the materials used in the unique wall painting in "St. Gorge" church in Staro Nagoričane. Moreover, the results of the analyses were found to be crucial in developing appropriate conservation-restoration strategies devoted to safeguarding this monument.

The analytical findings could contribute to future studies on the Byzantine iconography developed in the region of Macedonia and iconographic works attributed to the prominent painters Mihajlo Astrapa and Evtihij.

Acknowledgments. This research was supported by the EU-funded project "Conservation and revitalization of the cultural touristic site "St. George" - Staro
Nagoričane no. 10-27408/1 ('Direct Grant Contract'). Special thanks are directed to the Ministry of Culture of the Republic of Macedonia and the National Conservation Center - Skopje, for the support in the realization of this research.

\section{REFERENCES}

[1] B. Todić, Staro Nagoričine, RZZSK, Beograd, 1993, pp 25-27.

[2] Project for Conservation and revitalization of the cultural touristic site "St. George" - Staro Nagoričane, unpublished documentation, National Conservation Center - Skopje, Department for informative documentation, INDOC 08-25/27, 2015.

[3] Conservation-restoration project for preservation of the "St. George" church in Staro Nagoričane, unpublished documentation, National Conservation Center - Skopje, Department for informative documentation, INDOC 081299, 1997.

[4] B. H. Stuart, Analytical techniques in materials conservation, John Wiley and Sons, Ltd, 2007.

[5] D. Pinna, M. Galeotti, R. Mazzeo, Scientific Examination for the Investigation of Paintings: A Handbook for Conservators-Restorers, Centro Di, Firenze, 2009.

[6] L. Robeva-Čukovska, B. Minčeva-Šukarova, A. Lluveras-Tenorio, A. Andreotti, M. Perla Colombini, I. Nastova, Micro-Raman and GC/MC analysis to characterize the wall painting technique of Dicho Zograph in churches from Republic of Macedonia, J. Raman Spectrosc. 43 (11), 1685-1693 (2012).

[7] M. D. S. Gomez de Segura, Histochemical Staining Test for Protein and Oil Substances, ICCROM, Roma, 1994.

[8] M. Horgnies, M. Bayle, E. Gueit, Darque-Ceretti, M. Aucoutturier, Microstructure and surface properties of frescoes based on lime and cement: The influence of the artist's technique, Archaeometry 57 (2), 344-361 (2015).

[9] R. Piovesan, C. Mazzoli, L. Maritan, P. Cornale, Fresco and Lime-paint: An experimental study and objective 
criteria for distinguishing between these painting techniques, Archeometry 54 (4), 723-736 (2012).

[10] S. Mugnaini, A. Bagnoli, P. Bensi, F. Droghini, A. Scala, G. Guasparri, Thirteenth century wall paintings under the Siena Cathedral (Italy). Mineralogical and petrographic study of materials, painting techniques and state of conservation, J. Cult. Herit. 7, 171-185 (2006).

[11] Sister Daniilla, A. Tsakalof, K. Bairachtari, Y. Chryssoulakis, The Byzantine wall paintings from the Protaton Church on Mount Athos, Greece: Tradition and Science, J. Archaeol. Sci. 34 (12), 1971-1984 (2007).

[12] P. Mora, L. Mora, P. Philippot, Conservation of Wall Paintings, ICCROM, Rome, 1984.

[13] M. P. Merrifield, The Art of Fresco Painting in the Middle Ages and the Renaissance, Dover Publications, 2004.

[14] L. Čukovska, O. Grupče, B. Minčeva-Šukarova, I. Kuzmanovski, Characterization of salt efflorescence using target factor analysis. Development of the Method, $J$. Braz. Chem. Soc., 20 (1), 57-63 (2009).

[15] R. Nyquist, R. Kagel, Infrared Spectra of Inorganic Compounds, Academic Press, New York, 1971.

[16] N. V. Chukanov, Infrared Spectra of Mineral Species: Extended Library, Springer Science \& Business Media, 2013.

[17] R. M. Derrick, D. Stulik, M. J. Landry, Infrared Spectroscopy in Conservation Science, The Getty Conservation Institute, Los Angeles, 1999.

[18] R. L. Frost, D. L. Wain, W. N. Martens, B. J. Reddy, Vibrational spectroscopy of selected minerals of the rosasite group, Spectrochim. Acta, Part A 66 (4-5), 1068-1074 (2007).

[19] F. Ospitali, D. Bersani, G. D. Lonardo, P. P. Lottici, 'Green earths': vibrational and elemental characterization of glauconites, celadonites and historical pigments J. Raman Spectrosc. 39, 1066-1073 (2008).

[20] N. Eastaugh, V. Walsh, T. Chaplin, R. Siddall, Pigment Compendium: A Dictionary and Optical Microscopy of Historical Pigments, $1^{\text {st }}$ Ed., Butterworth Heinemann, London, 2008.

[21] S. Akyuz, T. Akyuz, G. Emre, A. Gulec, S. Basaran, Pigment analyses of a portrait and paint box of Turkish artist Feyhaman Duran (1886-1970): The EDXRF, FTIR and micro Raman spectroscopic studies, Spectrochim. Acta A 89, 74-81 (2012).

[22] L. Berzina-Cimdina, N. Borodajenko, Research of calcium phosphates using Fourier Transform Infrared Spectroscopy, Infrared Spectroscopy - Materials Science, Engineering and Technology, Prof. Theophanides Theophile (Ed.), (2012). InTech, http://www.intechopen.com/ books/infrared-spectroscopy-materials-science-engineering-and-technology/research-of-calcium-phosphatesusing-fourier-transformation-infrared-spectroscopy.

[23] Shipman, P., Foster, G., Schoeninger, M., 'Burnt bones and teeth: an experimental study of color, morphology, crystal structure and shrinkage', J. Archaeol. Sci. 11, 307-325 (1984).

[24] E. Tomasini, G. Siracusano, M. S. Maier, Spectroscopic, morphological and chemical characterization of historic pigments based on carbon. Paths for the identification of an artistic pigment, Microchem. J. 102, 28-37 (2012).

[25] A. Veiga, J. Mirao, A. J. Candeias, P. S. Rodrigues, D. M. Teixeira, V. S. F. Muralha, J. G. Teixeira, Pigment analysis of Portuguese portrait miniatures of 17th and 18th centuries by Raman microscopy and SEM-EDS, $J$. Raman Spectrosc. 45 (10), 947-957 (2014).

[26] G. A. Mazzocchin, F. Agnoli, S. Mazzocchin, I. Colpo, Analysis of pigments from Roman wall paintings found in Vicenza, Talanta 65, 565-572 (2003).

[27] J. Van der Weerd, A. Van Loon, J. J. Boon, FTIR studies of the effects of pigments on the aging of oil, Stud. Conserv. 50, 3-22 (2005).

[28] R. Mazzeo, S. Prati, M. Quaranta, E. Joseph, E. Kendix, M. Galeotti, Attenuated total reflection micro FTIR characterization of pigment-binder interaction in reconstructed paint films, Anal. Bioanal. Chem. 392, 65-76 (2008).

[29] F. Rosi, A. Daveri, C. Miliani, G. Verri, P. Benedetti, F. Pique, B. G. Brunetti, A. Sgamellotti, Non-invasive identification of organic materials in wall painting by fiber optic reflectance infrared spectroscopy: A statistical multivariate approach, Anal. Bioanal. Chem. 395 (7), 2097-2106 (2009).

[30] V. Otero, D. Sanches, C. Montagner, M. Vilarigues, L. Carlyle, J. A. Lopes, M. J. Melo, Characterization of metal carboxylates by Raman and infrared spectroscopy in works of art, J. Raman Spectrosc. 45, 1197-1206 (2014).

[31] N. A. Nikonenko, D. K. Buslov, N. I. Sushko, R. G. Zhbankov, Investigation of stretching vibrations of glycosidic linkages in disaccharides and polysaccharides with use of IR spectra deconvolution. Biopolymers 57 (4), 257-62 (2000).

[32] J. Lojewska, P. Miskowiec, T. Lojewski, L. M. Proniewicz, Cellulose oxidative and hydrolytic degradation: In situ FTIR approach, Polym. Degrad. Stab. 88, 512520 (2005).

[33] A. Srivastava, V. Mishra, P. Singh, A. Srivastava, R. Kumar, Comparative study of thermal degradation behavior of graft copolymers of polysaccharides and vinyl monomers, J. Therm. Anal. Calorim. 107, 211-223 (2012).

[34] P. Ropret, R. Zoubek, A. S. Škapin. P. Bukovec, Effects of ageing on different binders for retouching and on some binder-pigment combinations used for restoration of wall paintings, Mater. Charact. 58 (11-12), 11481159 (2007).

[35] C. Liu, Q. Liu, J. Sun, B. Jiang, J. Yan, Extraction of water-soluble polysaccharide and the antioxidant activity from Semen cassia, J. Food Drug Anal. 22 (4), 492-499 (2014).

DOI: http://dx.doi.org/10.1016/j.jfda.2014.01.027

[36] H. Jedrzejewska, Old mortars in Poland: A new method of investigation, Stud. Conserv. 5 (4), 132-138 (1960).

[37] J. I. Alvarez, A. Martin, P. J. G. Casado, I. Navarro, A. Zornoza, Methodology and validation of a hot hydrochloric acid attack for the characterization of ancient mortars. Cem. Concr. Res. 29 (7), 1061-1065 (1999). 
[38] J. I. Alvarez, I. Navarro, P. J. G. Casado, Thermal, mineralogical and chemical studies of the mortars used in the cathedral of Pamplona (Spain), Thermochim. Acta 365 (1), 177-187 (2000).

[39] F. Casadio, G. Chiari, S. Simon, Evaluation of binder/aggregate ratios in archaeological lime mortars with carbonate aggregate: A comparative assessment of chemical, mechanical and microscopic approaches, $A r$ chaeometry 47 (4), 671-689 (2005).
[40] P. Maravelaki-Kalaitzaki, A. Bakolas, A. Moropoulou, Physico-chemical study of Cretan ancient mortars, $\mathrm{Cem}$. Concr. Res. 33, 651-661 (2003).

[41] MKC EN 1015-1:2009/A1:2009: Methods of test for mortar for masonry - Part 1: Determination of particle size distribution by sieve analysis.

[42] ISO 14688-1:2002 - Geotechnical investigation and testing - Identification and classification of soil - Part 1: Identification and description. 